\title{
PENINGKATAN KOMPETENSI GURU DALAM MENYUSUN INSTRUMEN PENILAIAN HASIL BELAJAR MELALUI SUPERVISI AKADEMIK TEKNIK KELOMPOK
}

\author{
Oleh: Siti Mariyah \\ SD Pundung, Imogiri, Bantul \\ Email: sitimariyah.sutapa@gmail.com
}

\begin{abstract}
The purpose of this study was to improve teacher competency in compiling learning outcomes instruments through academic supervision of group techniques at Pundung Elementary School, Imogiri, in 2017/2018 academic year. This study is a school action research conducted in three cycles. Each cycle carried out in two meetings consisted of four steps, namely planning, action, evolution, and reflection. The subjects were 14 elementary school teachers at Pundung, Imogiri, consisting of 10 classroom teachers and 4 subject teachers. The results of the study show that the group technique applied in academic supervision may improve the ability of the teacher in compiling the learning outcomes instruments. The average values of teachers in compiling learning outcomes instruments were increased from cycle I, Cycle II, and Cycle III, i.e. 69, 81 and 88 respectively. The observations on the instruments in Cycle I revealed 4 teachers (28.6\%) performed substantial qualification, followed with 13 teachers (92.9\%) performed good qualification in Cycle II, and 11 teachers (79\%) performed very good qualifications in Cycle III.
\end{abstract}

Keywords: teacher competence, academic supervision.

\section{PENDAHULUAN}

Undang-undang Guru dan Dosen menyebutkan bahwa guru adalah pendidik profesional yang mendidik, mengajar, membimbing, mengarahkan, melatih, menilai, dan mengevaluasi peserta didik pada pendidikan anak usia dini pada jalur pendidikan formal, pendidikan dasar, dan pendidikan menengah. Dari pernyataan tersebut jelas tugas guru itu tidak hanya mengajarkan ilmu kepada anak atau siswa tetapi banyak tugas yang harus diemban guru. Sehubungan dengan tugas guru tersebut, maka seorang guru harus memiliki kompetensi sebagai syarat menjadi guru yang merupakan pekerjaan profesional. Adapun kompetensi yang dimiliki seorang guru menurut undangundang nomor 20 tahun 2003 tentang sistem pendidikan nasional adalah kompetensi pengelolaan pembelajaran, pengembangan potensi, penguasaan akademik, dan sikap kepribadian.

Pelaksana supervisi akademik ini adalah kepala sekolah dalam pembinaan profesional guru dan pelaksanaan proses belajar mengajar. Dalam Permendiknas RI nomor 13 tahun 2007 tentang Standar
Kompetensi Kepala Sekolah atau Madrasah dinyatakan bahwa salah satu kompetensi yang harus dimiiki oleh kepala sekolah adalah mampu melaksanakan supervisi. Pesan kepala sekolah sangat menentukan keberhasilan guru dan siswa dalam mencapai suatu tujuan pendidikan, artinya kepala sekolah sebagai salah satu supervisor untuk dapat membina serta mengarahkan sekolah tersebut melalui guru. Berdasarkan pemaparan di atas, maka perlu dilakukan penelitian dengan judul: Apakah dengan supervisi akademik teknik kelompok dapat meningkatkan kompetensi guru dalam menyusun instrumen penilaian hasil belajar?

Peraturan Pemerintah RI nomor 19 tahun 2015 tentang standar Nasional Pemerintah pasal 28 menyatakan bahwa pendidik harus memiliki kualifikasi akademik dan kompetensi sebagai agen pembelajaran, sehat jasmani dan rohani, serta memiliki kemampuan untuk mewujudkan tujuan pendidikan nasional. Kualifikasi akademik adalah tingkat pendidikan minimal yang harus dipenuhi seorang pendidik yang dibuktikan dengan ijazah dan atau sertifikat keahlian yang relevan sesuai ketentuan perundang-undangan 
yang berlaku, sedang kompetensi sebagai agen pembelajaran pada jenjang pendidikan dasar dan menengah meliputi: kompetensi paedagogik, kompetensi kepribadian, kompetensi profesional dan kompetensi sosial.

Menurut Mc.Ashan dalam Mulyasa (2003: 38) kompetensi dapat diartikan sebagai pengetahuan, keterampilan, dan kemampuan yang dikuasai seseorang telah menjadi bagian dari dirinya sehingga dia dapat melakukan perilaku-perilaku kognitif, afektif dan psikomoto dengan sebaik- baiknya.

Undang-undang nomor 14 tahun 2005 tentang Guru dan Dosen menegaskan bahwa guru wajib memiliki kualifikasi akademik, kompetensi, sertifikat pendidik, sehat jasmani san rohani, dan memenuhi kualifikasi lain yang dipersyaratkan satuan pendidikan tinggi tempat bertugas, serta memiliki kemampuan untuk mewujudkan tujuan pendidikan nasional. Kompetensi guru sesuai Undangundang Guru dan Dosen dan sesuai dengan Peraturan Pemerintah no. 19/2005 meliputi 4 kompetensi, yaitu: kompetensi pedagogik, kompetensi profesional, kompetensi sosial, dan kompetensi kepribadian.

Penilaian (assessment) menurut Mundilarto (2012: 14) adalah penafsiran hasil pengukuran dan penentuan kategori berdasarkan kriteria baku yang digunakan sebagai acuan. Sedangkan penilaian hasil belajar masih menurut Mundilarto adalah proses pengumpulan dan penggunaan informasi oleh guru untuk pemberian keputusan terhadap hasil belajar peserta didik berdasarkan tahapan kemajuan belajarnya sehingga didapatkan profil kemampuan peserta didik sesuai dengan kompetensi yang ditetapkan dalam kurikulum.

Permendiknas nomor 23 tahun 2016 menjrlaskan bahwa penilaian pendidikan adalah proses pengumpulan dan pengolahan informasi untuk menentukan pencapaian hasil belajar peserta didik. Penilaian hasil belajar tersebut dilaksanakan berdasarkan standar penilaian pendidikan yang berlaku secara nasional. Selanjutnya yang dimaksud penilaian hasil belajar oleh pendidik adalah proses pengumpulan informasi/bukti tentang capaian pembelajaran peserta didik dalam kompetensi sikap spiritual dan sikap sosial, kompetensi pengetahuan, dan kompetensi keterampilan yang dilakukan secara terencana dan sistimatis, selama dan setelah proses pembelajaran suatu kompetensi muatan pembelajaran untuk kurun waktu satu semester dan satu tahun pelajaran.

Jadi instrumen penilaian hasil belajar adalah alat yang digunakan oleh guru dalam proses pengumpulan data untuk memperoleh informasi keberhasilan peserta didik dalam menyerap materi pelajaran yang disampaikan oleh guru. Data yang diperoleh guru tersebut bisa dijadikan alat untuk memberikan skor nilai peserta didik, melihat ketercapaian KKM, perbaikan instrumen penilaian yang disusun, bahkan untuk memperbaiki kegiatan yang sudah dilaksanakaan oleh guru.

Secara umum tujuan penilaian adalah untuk: 1) mengetahui tingkat kompetensi peserta didik, 2) mengukur pertumbuhan dan perkembangan peserta didik, 3) mendiagnosa kesulitan peserta didik, 4) mengetahui hasil proses belajar mengajar, 5) mengetahui pencapaian kurikulum, 6) membantu dan mendorong peserta didik untuk lebih giat lagi, 7) membantu dan mendorong guru untuk mengajar lebih baik, 8) Sebagai upaya meningkatkan akuntabilitas lembaga, 9) sebagai upaya meningkatkan kualitas pendidikan.

Prinsip prinsip penilaian: a) sahih, yaitu penilaian didasarkan pada data yang mencerminkan kemampuan yang diukur, 2) obyektif, yaitu penilaian yang didasarkan pada prosedur dan kriteria yang jelas, tidak dipengaruhi subjektivitas penilai, c) adil, yaitu penilaian tidak menguntungkan atau merugikan peserta didik karena berkebutuhan khusus serta perbedaan latar belakang agama, suku, budaya, adat istiadat, status sosial ekonomi, dan gender, d) terpadu, yaitu penilaian oleh pendidik merupakan salah satu komponen yang tak terpisahkan dari kegiatan 
pembelajaran, e) terbuka, yaitu prosedur penilaian, kriteria penilaian, dan dasar pengambilan keputusan dapat diketahui oleh pihak yang berkepentingan, f) menyeluruh dan berkesinambungan, penilaian oleh pendidik mencakup semua aspek kompetensi dengan menggunakan berbagai teknik penilaian yang sesuai, untuk memantau perkembangan kemampuan peserta didik, g) sistematis, yaitu penilaian dilakukan secara berencana dan bertahap dengan mengikuti langkah-langkah baku, h) beracuan kriteria, yaitu penilaian didasarkan pada ukuran pencapaian kompetensi yang ditetapkan, i) akuntabilitas, yaitu penialain dapat dipertanggungjawabkan, baik dari segi teknik, prosedur maupun hasilnya.

Teknik penilaian berdasarkan Permendiknas nomor 23 tahun 2016 meliputi: a) Penilaian Sikap, ada dua macam: (1) Utama: observasi oleh guru kelas dan observasi oleh guru mata pelajaran, (2) Penunjang: Penilaian diri dan penilaian antar teman, b) Penilaian Pengetahuan: (1) Tes tertulis: Pilihan Ganda, Benar Salah, Menjodohkan, Isian/ Melengkapi, dan Uraian, (2) Tes Lisan: Perintah, kuis dan tanya jawab, (3) Penugasan: Tugas yang dilakukan secara individu atau kelompok di sekolah, di luar sekolah, dan di rumah, c) Penilaian Keterampilan meliputi: Kinerja, Proyek, dan Portofolio.

Dalam praktik pembelajaran di kelas masih sering ditemui guru-guru yang ditingkatkan profesionalismenya dalam proses belajar mengajarnya. Sering ada persepsi yang salah atau kurang tepat di mana tugas supervisor sering dimaknai sebagai tugas untuk mencari kesalahan atau untuk mengadili guru, padahal tujuannya untuk meningkatkan efektivitas dan efisiensi proses belajar mengajar. Ciri utama supervisi adalah perubahan dalam ke arah yang lebih baik, positif belajar mengajar lebih efektif dan efisien.

Langkah-langkah pelaksanaan Supervisi Akademik meliputi: 1) merencanakan supervisi mulai dari merencanakan supervisi melaksanakan supervisi, dan menindak lanjuti hasil supervisi, 2) melaksanakan supervisi yaitu menerapkan pendekatan supervisi yang tepat, menerapkan teknik supervisi yang tepat, menerapkan prinsip supervisi, 3) menindak lanjuti hasil supervisi yaitu melakukan evaluasi hasil supervisi dan, 4) menyusun program tindak lanjut .

Pendekatan supervisi akademik adalah tingkah laku supervisor dalam membagi tanggung jawab antara dirinya dengan guru yang sedang disupervisi, dalam menganalisis dan mengambil keputusan terhadap masalah pengajaran yang dihadapi oleh guru. Pendekatan supervisi akademik bisa dikelompokkan menjadi: 1) Pendekatan Langsung (Direct Service to Teachers): Supervisor memberi bantuan melalui komunikasi langsung kepada guru untuk memecahkan masalah-masalah pembelajaran, 2) Pendekatan tak langsung (Indirect Service to Teachers): Supervisor memberi bantuan kepada guru untuk memecahkan masalahmasalah pembelajaran melalui pihak lain: MGMP/PKG/KKG, pelatihan dalam jabatan (In-service Training) lokakarya, seminar supervisi oleh konsultan/pakar, supervisi oleh pengawas sekolah, karyawisata, kegiatan organisasi profesi.

Teknik supervisi: 1) Individual adalah pelaksanaan supervisi yang diberikan kepada guru tertentu yang mempunyai masalah khusus dan bersifar perorangan. Teknik ini dilakukan melalui: kunjungan kelas, observasi kelas, pertemuan individual, kunjungan antar kelas, menilai diri sendiri, dan 2) Teknik supervisi kelompok: Teknik supervisi kelompok adalah satu cara melaksanakan program supervisi yang ditujukan pada dua orang atau lebih. Kepada mereka diberikan layanan supervisi sesuai dengan permasalahan atau kebutuhan yang mereka hadapi. Menurut Gwyn dalam modul diklat kepala sekolah sekolah ada 13 teknik supervisi kelompok: 1) kepanitiaan-kepanitiaan, 2) kerja kelompok, 3) laboraturium kurikulum, 4) baca terpimpin, 5) demonstrasi pembelajara, 6) darmawisata, 
7) kuliah/study, 8) diskusi panel, 9) perpustakaan jabatan, 10) organisasi profesional, buletin supervisi, 11) buletin supervisi, 12) pertemuan guru), 13) lokakarya atau konferensi kelompok.

Prinsip supervisi akademik: 1) praktis artinya mudah dikerjakan sesuai kondisi sekolah, 2) sistematis artinya dikembangkan sesuai perencanaan program supervisi yang matang dan sesuai dengan tujuan pembelajaran, 3) objektif artinya masukan sesuai dengan aspek-aspek instrument, 4) realistis, artinya berdasarkan kenyataan sebenarnya, 5) antisipatif, artinya mampu menghadapi masalah-masalah yang mungkin terjadi, 6) konstruktif, artinya mampu menghadapi masalah-masalah yang mungkin terjadi, 7) konstribusi, artinya mengembangkan kreatifitas dan inovasi guru dalam mengembangkan pembelajaran, 8) kekurangan, artinya mempertimbangkan saling asih asih dan asuh dalam mengembangkan pembelajaran, 9) demokratis, artinya supervisor tidak boleh mendominasi pelaksanaan supervisi akademik, 10) aktif, artinya guru dan supervisor harus aktif berpartisipasi, 11) humanis, artinya mampu menciptakan hubungan kemanusiaan yang harmonis, terbuka, jujur, sabar antusias, dan penuh humor, 12) berkesinambungan, artinya supervisi akademik dilakukan secara teratur dan berkelanjutan oleh kepala sekolah, 13) terpadu, artinya menyatu dengan program pendidikan, 14) komprehensif, artinya memenuhi tujuan supervisi akademik.

\section{METODE PENELITIAN}

Penelitian ini dilaksanakan di SD Pundung, Imogiri, Bantul, dengan alamat jalan Mangunan Km. 1 Kradenan, Girirejo, Imogiri, dan dilaksanakan pada semester I tahun pelajaran 2017/2018 selama 3 bulan, dari Juli sampai Oktober 2017. Subyek penelitian adalah guru-guru SD Pundung, Imogiri, Bantul. Guru SD Pundung tahun pelajaran 2017/2018 ada 14 orang terdiri dari 10 guru kelas dan 4 guru pelajaran. Jenis penelitian kelas ini adalah penelitian tindakan (action research). Penelitian tindakan menurut Agus Wasisto (2016:42) adalah suatu bentuk penilaian refleksi diri yang dilakukan oleh para partisipan dalam situasi-situasi social (termasuk pendidikan) untuk memperbaiki rektak yang dilakukan sendiri. Dalam penelitian ini peneliti tindakan yang digunakan adalah penelitian tindakan sekolah (PTS). Penelitian tindakan sekolah adalah penelitian yang dilakukan oleh kepala sekolah atau pengawas sekolah. Ciri khusus dari penelitian tindakan sekolah adalah adanya tindakan (action) yang nyata. Tindakan ini dilakukan pada keadaan yang sebenarnya dan ditujukan untuk memecahkan permasasalahpermasalahan praktis dalam peningkatan mutu proses dan hasil kepengawasan. Peneliti tindakan ini menggunakan model Kemmis dan Mc. Taggart, dimana peneliti terdiri atas empat tahap yaitu perencanaan (planning), pelaksanaan (acting), pengamatan (observing), dan refleksi (reflecting). Hubungan keempat komponen tersebut dipandang sebagai satu siklus. Adapun alur dari penelitian ini adalah sebagai berikut:

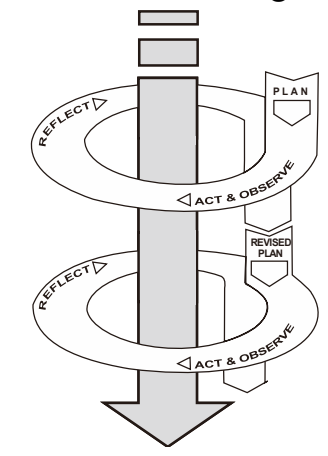

Gambar 1. Desain penelitian model Kemmis dan Mc. Taggart

Penelitian ini dilaksanakan dalam 3 siklus setiap siklus terdiri dari empat tahapan yaitu (1) Perencanaan (planning), (2) Pelaksanaan (accing), (3) Pengamatan (observing), dan (4) Refleksi (reflecting). Teknik analisis data pada penelitian ini menggunakan analisis deskriptif kualitatif terhadap data penelitian tindakan sekolah dengan tahapan sebagai berikut: menyeleksi 
data, menyederhanakan, mengklasifikasi, memfokuskan, mengorganisasi (mengaitkan gejala secara sistematis dan logis) membuat abstraksi atas kesimpulan makna hasil analisis. Model analisis kualitatif yang terkenal adalah model Miles \& Hubberman (1992: 20) yang meliputi: reduksi data (memilah data penting, relevan, dan bermakna dari data yang tidak berguna), sajian deskriptif (narasi, visual gambar, tabel) dengan alur sajian yang sistematis dan logis penyimpulan dari hasil yang disajikan (dampak PTS dan efektivitasnya).

\section{HASIL PENELITIAN Siklus I}

Siklus pertama dilaksanakan selama 2 kali pertemuan dengan masing-masing pertemuan mengobservasi 10 orang guru kelas dan 2 orang guru mata pelajaran Pendidikan Agama Islam dan 2 guru mata pelajaran Pendidikan Jasmani Olahraga dan Kesehatan. Siklus pertama pertemuan 1 dilaksanakan pada hari Sabtu tanggal 5 Agustus 2017, dan pertemuan kedua dilaksanakan hari Sabtu tanggal 19 Agustus 2017. Pada pertemuan pertama guru secara bersama-sama menyusun instrumen penilaian sesuai tugasnya masingmasing dan sesuai kemampuan masingmasing pula, dengan bimbingan supervisor. Setelah selesai supervisor mengamati instrumen yang dibuat guru menggunakan instrumen yang sudah disiapkan dan kolabolator mengamati supervisor dalam melaksanakan supervisi dengan berpedoman pada instrumen observasi, sementara guru bertanya jawab dan belajar bersama dengan teman sesama tentang penyusunan instrumen penilaian.

Penyusunan instrumen penilaian yang dibuat guru pada tindakan Siklus I masih ditemui beberapa kekurangan: 1) Penulisan soal belum disertai perintah yang jelas, 2) Rumusan soal menggunakan bahasa yang sulit dipahami anak, 3) pilihan jawaban panjang pendek kalimatnya tidak sama, urutan angka atau waktu tidak berurutan, masih mengandung jawaban semua pilihan jawaban betul semua atau salah semua, gambar, grafik tabel, diagram kurang jelas.

Tabel 1. Hasil observasi Instrumen Penilaian Siklus I

\begin{tabular}{ccccccc}
\hline \multirow{2}{*}{ No } & \multirow{2}{*}{ Nama } & \multicolumn{2}{c}{ Pertemuan 1 } & \multicolumn{2}{c}{ Pertemuan 2 } & \multirow{2}{*}{ Rerata } \\
\cline { 3 - 6 } & & Nilai & Kategori & Nilai & Kategori & \\
\hline 1. & YM & 62 & Cukup baik & 71 & Cukup baik & 67 \\
\hline 2. & SN & 60 & Kurang baik & 68 & Cukup baik & 64 \\
\hline 3. & SP & 63 & Cukup baik & 72 & Cukup baik & 68 \\
\hline 4. & SR & 75 & Baik & 77 & Baik & 76 \\
\hline 5. & SE & 62 & Cukup baik & 69 & Cukup baik & 67 \\
\hline 6. & SD & 76 & Baik & 78 & Baik & 77 \\
\hline 7. & MR & 60 & Kurang baik & 70 & Cukup baik & 65 \\
\hline 8. & ST & 62 & Cukup baik & 65 & Cukup baik & 64 \\
\hline 9. & ANF & 65 & Cukup baik & 70 & Cukup baik & 68 \\
\hline 10. & TP & 65 & Cukup baik & 69 & Cukup baik & 67 \\
\hline 11. & SKh & 76 & Baik & 78 & Baik & 77 \\
\hline 12 & UH & 65 & Cukup baik & 69 & Cukup baik & 67 \\
\hline 13 & TS & 64 & Cukup baik & 69 & Cukup baik & 67 \\
\hline 14 & DD & 75 & Baik & 78 & Baik & 77 \\
\hline & Rerata & 66 & Cukup baik & 72 & Cukup baik & 69 \\
\hline
\end{tabular}

Hasil pelaksanaan supervisi pada pertemuan pertama siklus I diperoleh hasil bahwa nilai tertinggi 76 dengan kategori baik dan nilai terendah 60 dengan kategori kurang baik dan rata-rata 66 dengan kategori cukup baik juga. Pada siklus I pertemuan pertama ini ada 2 orang guru (14,3\%) dari 14 guru yang mendapat nilai 60 dengan kategori kurang baik. Sedangkan $28,6 \%$ guru yaitu 4 orang sudah mencapai kategori nilai baik. Nilai ratarata penyusunan instrumen penilaian guruguru 66 dengan kategori cukup baik. 
Hasil supervisi pada pertemuan kedua siklus I adalah nilai tertinggi yang diperoleh guru dalam melaksanakan penyusunan instrumen penilaian 78 dengan kategori baik, nilai terendah 65 dengan kategori cukup baik, rata-rata 72 dengan kategori cukup baik.

Rekapitulasi dari hasil analisis rata-rata kemampuan guru dalam menyusun instrumen penilaian melalui supervisi akademik teknik kelompok siklus I dapat dilihat dari tabel berikut:

Tabel 2. Rekapitulasi Hasil Siklus I

\begin{tabular}{ccc}
\hline Kategori & Jumlah & Prosentase \\
\hline Sangat baik & 0 & $0 \%$ \\
\hline Baik & 4 & $28,6 \%$ \\
\hline Cukup baik & 10 & $71,4 \%$ \\
\hline Kurang baik & 0 & $0 \%$ \\
\hline
\end{tabular}

Refleksi siklus I membahas kekurangan sebagian guru dalam menyusun instrumen penilaian masih belum sesuai dengan indikator, petunjuk mengerjakan masih belum jelas kadang tidak ditulis, ada pilihan jawaban yang benar semua atau salah semua, panjang pendek kalimat jawaban belum sama, bahasa yang digunakan dalam menyusun soal sulit dipahami siswa, dan belum menggunakan kaidah bahasa yang benar. Kegiatan terakhir refleksi siklus pertama supervisor menyampaikan kepada para guru rencana kegiatan pada siklus kedua berdasarkan refkesi pada siklus I.

\section{Siklus II}

Pelaksanaan Siklus II dilaksanakan dalam dua pertemuan, pertemuan pertama dilaksanakan pada hari Sabtu tanggal 2 September 2017. Pertemuan kedua siklus kedua dilaksanakan pada hari Sabtu tanggal 16 September 2017. Supervisi pada Siklus II pertemuan pertama dimulai dengan penjelasan supervisor melalui penayangan layar LCD hasil diklat penulisan soal, dengan tujuan para guru lebih paham lagi bagaimana cara menyusun instrumen penilaian sehingga ke depannya diharapkan mereka bisa menyusun soal yang baik. Setelah penjelasan dari supervisor dan tanyajawab masing-masing. Supervisor mengamati dan menganalisis instrumen penilaian yang sudah berhasil disusun guru satu persatu dengan berpedoman pada instrumen seperti pada siklus I. Kolaborator mengamati supervisor menggunakan instrumen seperti siklus I sejak awal sampai akhir kegiatan.

Tabel 3. Hasil Observasi Instrumen Penilaian Siklus II

\begin{tabular}{|c|c|c|c|c|c|c|}
\hline \multirow{2}{*}{ No } & \multirow{2}{*}{ Nama } & \multicolumn{2}{|c|}{ Pertemuan 1} & \multicolumn{2}{|c|}{ Pertemuan 2} & \multirow{2}{*}{ Rerata } \\
\hline & & Nilai & Kategori & Nilai & Kategori & \\
\hline 1. & YM & 78 & Baik & 82 & Baik & 80 \\
\hline 2. & SN & 75 & Cukup baik & 80 & Baik & 78 \\
\hline 3. & $\mathrm{SP}$ & 80 & Baik & 82 & Baik & 81 \\
\hline 4. & SR & 81 & Baik & 86 & Sangat baik & 84 \\
\hline 5. & SE & 78 & Baik & 80 & Baik & 79 \\
\hline 6. & SD & 82 & Baik & 90 & Sangat baik & 86 \\
\hline 7. & MR & 76 & Baik & 80 & Baik & 78 \\
\hline 8. & ST & 75 & Cukup baik & 80 & Baik & 78 \\
\hline 9. & ANF & 78 & Baik & 83 & Baik & 81 \\
\hline 10. & $\mathrm{TP}$ & 78 & Baik & 83 & Baik & 81 \\
\hline 11. & SKh & 82 & Baik & 86 & Sangat baik & 84 \\
\hline 12 & UH & 82 & Baik & 83 & Baik & 83 \\
\hline 13 & TS & 76 & Baik & 83 & Baik & 80 \\
\hline \multirow[t]{2}{*}{14} & DD & 76 & Baik & 86 & Sangat baik & 81 \\
\hline & Rerata & 78 & Baik & 83 & Baik & 81 \\
\hline
\end{tabular}

Hasil pelaksanaan supervisi pada petemuan pertama Siklus II diperoleh hasil yang signifikan yaitu nilai tertinggi 82 dengan kategori baik nilai terendah 75 dengan kategori cukup baik dan rata-rata 78 dengan kategori baik. Pada Siklus II pertemuan pertama ada 2 (14\%) dari 14 guru yang mendapat nilai 75 dengan kategori cukup baik. 
Sedang $86 \%$ guru yaitu 12 mencapai kategori baik. Nilai rata-rata penyusunan instrumen penilaian adalah 78 dengan kategori baik.

Hasil supervisi pada pertemuan kedua Siklus II lebih baik yaitu nilai tertinggi 90 dengan kategori sangat baik, nilai terendah 80 dengan kategori baik, nilai rata-rata 83 dengan kategori baik. Rekapitulasi hasil siklus II dapat dilihat pada tabel berikut:

Tabel 4. Rekapitulasi Hasil Siklus II

\begin{tabular}{ccc}
\hline Kategori & Jumlah & Prosentase \\
\hline Sangat baik & 1 & $7,1 \%$ \\
\hline Baik & 13 & $92,9 \%$ \\
\hline Cukup baik & 0 & $0 \%$ \\
\hline Kurang baik & 0 & $0 \%$ \\
\hline
\end{tabular}

\section{Siklus III}

Siklus III dilaksanakan pada hari Sabtu tanggal 7 Oktober 2017 dan pertemuan kedua pada hari Sabtu tanggal 21 Oktober 2017. Pada siklus III pertemuan pertama dan kedua dalam menyusun instrumen penilaian guru diminta untuk saling melakukan koreksi terhadap hasil kerja rekannya sebelum diserahkan kepada supervisor dengan tujuan mereka bisa saling melakukan koreksi terhadap kekurangan rekan guru dan bisa membantu memberikan solusi maupun perbaikan untuk kekurangan rekannya. Hal tersebut dikarenakan pada siklus kedua semua guru sudah diberi bekal penjelasan dari supervisor mengenai tata cara penyusunan soal hasil diklat supervisor. Diharapkan pada siklus III ini para guru sudah betul-betul mahir dalam menyusun instrumen penilaian karena pada siklus II sudah terlihat hasil yang bagus.

Tabel 5.Hasil Observasi Instrumen Penilaian Siklus III

\begin{tabular}{clccccc}
\hline \multirow{2}{*}{ No } & \multirow{2}{*}{ Nama } & \multicolumn{2}{c}{ Pertemuan 1 } & \multicolumn{2}{c}{ Pertemuan 2 } & \multirow{2}{*}{ Rerata } \\
\cline { 3 - 6 } 1. & YM & 86 & Sangat baik & 92 & Sangat baik & 89 \\
\hline 2. & SN & 82 & Baik & 84 & Baik & 83 \\
\hline 3. & SP & 86 & Sangat baik & 90 & Sangat baik & 88 \\
\hline 4. & SR & 90 & Sangat baik & 92 & Sangat baik & 91 \\
\hline 5. & SE & 84 & Baik & 88 & Sangat baik & 86 \\
\hline 6. & SD & 92 & Sangat baik & 96 & Sangat baik & 94 \\
\hline 7. & MR & 84 & Baik & 86 & Sangat baik & 85 \\
\hline 8. & ST & 82 & Baik & 84 & Baik & 83 \\
\hline 9. & ANF & 86 & Sangat baik & 89 & Sangat baik & 88 \\
\hline 10. & TP & 86 & Sangat baik & 92 & Sangat baik & 89 \\
\hline 11. & SKh & 82 & Baik & 84 & Baik & 83 \\
\hline 12 & UH & 86 & Sangat baik & 90 & Sangat baik & 88 \\
\hline 13 & TS & 90 & Sangat baik & 92 & Sangat baik & 91 \\
\hline 14 & DD & 84 & Baik & 88 & Sangat baik & 86 \\
\hline & Rerata & 86 & Sangat baik & 89 & Sangat baik & 87 \\
\hline
\end{tabular}

Hasil pelaksanaan supervisi pada pertemuan pertama siklus III diperoleh hasil yang nilai tertinggi 94 dengan kategori sangat baik nilai terendah 83 dengan kategori baik yang lain sudah mencapai nilai kategori sangat baik. Hasil supervisi pada pertemuan kedua siklus III $79 \%$ yaitu 11 orang guru dari 14 orang guru sudah mencapai nilai dengan kategori sangat baik dan $21 \%$ guru yaitu 3 dari 14 guru mencapai nilai dengan kategori baik. Nilai tertinggi 96 dan nilai terendah 84. Jadi hasil penilaian terhadap kemampuan guru dalam menyusun instrumen penilaian pada siklus III ini sudah melampaui target penelitian.

Rekapitulasi dari hasil analisis rata-rata kemampuan guru dalam menyusun instrumen penilaian melalui supervisi akademik teknik kelompok siklus III dapat dilihat dari tabel berikut:

Tabel 6. Rekapitulasi Hasil Siklus III

\begin{tabular}{ccc}
\hline Kategori & Jumlah & Prosentase \\
\hline Sangat baik & 11 & $79 \%$ \\
\hline Baik & 3 & $21 \%$ \\
\hline Cukup baik & 0 & $0 \%$ \\
\hline Kurang baik & 0 & $0 \%$ \\
\hline
\end{tabular}




\section{PEMBAHASAN}

Supervisi dimulai dari perencanaan yaitu dengan menyusun program dan jadwal supevisi, menyosialisasikan kepada guru tentang waktu akan dilaksanannya supervisi, instrumen yang akan digunakan pada waktu melaksanakan supervisi sehingga diharapkan guru bisa mempersiapkan sesuai instrumen, menyiapkan instrumen dan materi yang akan digunakan untuk melaksanakan supervisi. Pelaksanaan supervisi siklus I setelah supervisor memberikan pengantar guru langsung menyusun instrument penilaian hasil belajar, supervisor mengamati hasil kerja guru dan diamati supervisor. Instrumen penilaian hasil belajar yang disusun guru pada Siklus I masih ditemui banyak kekurangan, sehingga perlu ada tindakan perbaikan pada Siklus II agar guru bisa menyusun instrumen penilain yang lebih baik dan sesuai standar.

Pada siklus II sebelum guru menyusun instrumen penilaian hasil belajar terlebih dahulu supervisor memberikan penjelasan cara menyusun soal dari hasil diklat melalui layar LCD. Guru memperbaiki dan dilanjutkan dengan Tanya jawab tentang materi dilanjut guru menyusun instrumen penilaian hasil belajar sesuai tugas mereka. Supervisor mengamati proses dan hasil kerja guru dalam menyusun instrumen penilaian hasil belajar dan diamati oleh kolaborator. Hasil pengamatan instrumen penilaian yang disusun guru sudah meningkat signifikan.

Siklus III guru saling menukarkan hasil karyanya lalu dibahas bersama disesuaikan dengan standar yang berlaku. Supervisor mengamati instrumen penilaian hasil belajar yang disusun guru setelah didiskusikan antar teman dan supervisor diamati oleh kolaborator. Hasil pengamatan instrumen penilaian yang disusun guru pada siklus III lebih meningkat dari siklus II, dan penelitian ini dihentikan pada siklus III.

Hasil observasi kolaborator memberikan manfaat bagi kepala sekolah dalam merencanakan, melaksanakan, mengevaluasi, dan menindaklanjuti hasil supervisi akademik, sehingga program kerja kepala sekolah bisa berjalan lebih baik. Salah satu kompetensi kepala sekolah yaitu dalam supervisi akademik bisa meningkat, dan akan berdampak pada perencanaan dan pelaksanaan kegiatan pembelajaran oleh guru juga semakin baik. Semua itu akan berdampak positif kepada hasil belajar siswa juga akan semakin baik.

Berikut adalah tabel hasil analisis kemampuan guru dalam menyusun instrumen penilaian melalui supervisi akademik.

Tabel 7. Rata-rata Hasil Observasi Penyusunan Instrumen Penilaian oleh Guru No Nama Siklus I Siklus II Siklus III

\begin{tabular}{cllll}
\hline 1. & YM & 67 & 80 & 89 \\
\hline 2. & SN & 64 & 78 & 85 \\
\hline 3. & SP & 68 & 81 & 89 \\
\hline 4. & SR & 76 & 84 & 91 \\
\hline 5. & SE & 67 & 79 & 86 \\
\hline 6. & SD & 77 & 86 & 94 \\
\hline 7. & MR & 65 & 78 & 85 \\
\hline 8. & ST & 64 & 78 & 85 \\
\hline 9. & ANF & 68 & 81 & 88 \\
\hline 10. & TP & 67 & 81 & 89 \\
\hline 11. & SKh & 77 & 84 & 83 \\
\hline 12. & UH & 67 & 83 & 88 \\
\hline 13. & TS & 67 & 80 & 91 \\
\hline 14. & DD & 77 & 81 & 86 \\
\hline & Rerata & 69 & 81 & 88 \\
\hline
\end{tabular}

Rekapitukasi dari hasil analisis kemampuan guru dalam menyusun instrumen penilaian melalui supervisi akademik teknik kelompok dari siklus I sampai siklus III dilihat dari tabel berikut:

Tabel 5. Rekap hasil Analisis dari Siklus I, II, dan III.

\begin{tabular}{ccccccc}
\hline Kategori & Siklus I & Prosentase & Siklus II & Prosentase & Siklus III & Prosentase \\
\hline Sangat baik & 0 & $0 \%$ & 1 & $7,1 \%$ & 11 & $79 \%$ \\
\hline Baik & 4 & $28,6 \%$ & 13 & $92,9 \%$ & 3 & $21 \%$ \\
\hline Cukup baik & 10 & $71,4 \%$ & 0 & $0 \%$ & 0 & $0 \%$ \\
\hline Kurang baik & 0 & $0 \%$ & 0 & $0 \%$ & 0 & $0 \%$ \\
\hline
\end{tabular}


Peningkatan kemampuan guru dalam menyusun instrumen penilaian hasil belajar dapat dilihat melalui hasil supervisi akademik teknik kelompok yaitu pada siklus I nilai ratarata guru dalam menyusun instrumen penilaian 69 dengan kategori cukup baik, 4 orang guru $(28,6 \%)$ mencapai nilai kategori baik 10 orang guru $(71,4 \%)$ mencapai nilai kategori cukup baik. Siklus II nilai rata-rata 81 dengan kategori baik, 1 orang guru $(7,1 \%)$ mendapat nilai kategori sangat baik 13 orang (92,9\%) mendapat nilai kategori baik. Siklus III nilai rata-rata 88 dengan kategori sangat baik, 11 orang guru $(79 \%)$ mendapat nilai kategori sangat baik dan 3 orang guru (21\%) mendapat nilai kategori baik.

\section{KESIMPULAN}

Hasil penelitian menunjukkan bahwa dalam menyusun instrumen penilaian siklus I oleh guru diperoleh rata-rata 69 dengan kualifikasi cukup baik $71,4 \%$ (10 orang). Hasil yang diperoleh pada siklus II rata- rata 81 dengan kualifikasi baik 92,9\% (13 orang). Sedangkan hasil yang diperoleh pada siklus III rata-rata 88 dengan kualifikasi sangat baik $79 \%$ (11 orang).

Berdasarkan hasil yang diperoleh di atas, maka teknik kelompok dalam menyusun instrumen penilaian hasil belajar melalui supervisi kelompok dapat meningkatkan kemampuan kompetensi guru SD Pundung, Imogiri tahun pelajaran 2017/2018.

\section{DAFTAR PUSTAKA}

Arikunto, S, dkk. (2004). Penelitian Tindakan Kelas. Jakarta: Bumi Aksara.

BSNP. (2016). Standar Penilaian Pendidikan. Jakarta: Departemen Pendidikan Nasional Dirjen Dikdasmen.

Departemen Pendidikan Nasional. (2001). Peraturan Menteri Pendidikan Nasional no. 13 Tahun 2007 Tentang Standar Kepala Sekolah/madrasah. Jakarta:-

Direktorat Pembinaan Sekolah Dasar. (2016). Panduan Penilaian untuk Sekolah Dasar (SD). Jakarta: -

Direktorat Tenaga Kependidikan. (2010). Pedoman Standarisasi Guru. Jakarta: BP Panca Bhakti.

Mulyasa. (2003). Menjadi Kepala Sekolah Profesional. Bandung: PT. Remaja Rosdakarya.

Mundilarto. (2012). Penilaian Hasil Belajar. Yogyakarta: UNY PREES.

Peraturan Pemerintah RI No 47 Tahun 2008 tentang Wajib Belajar dan No 48 Tahun 2008 tentang Pandanaan Pendidikan. Jakarta: CV Mitra Sarana Media.

Peraturan Pemerintah RI. (2015). Standar Nasional Pendidikan. Jakarta: Departemen Pendidikan Nasional.

Suyanto. (1995). Pedoman Pelaksanaan Penelitian Tindakan Kelas. Jakarta: Depdikbud.

Undang-undang RI No. 14 tahun 2005 tentang Guru dan Dosen. Jakarta.

Wasisto Dwi Doso Warso, Agus. (2016). Penelitian kepengawasan dan Tindakan Sekolah. Klaten: Widyapustaka Publisher. 